Canadian Art Review

\title{
Double Exposure: Photography and the Great War Paintings of Frank Johnston, Arthur Lismer, and Frederick Varley
}

\section{Laura Brandon}

Volume 39, numéro 2, 2014

Photography and War

La photographie et la guerre

URI : https://id.erudit.org/iderudit/1027746ar

DOI : https://doi.org/10.7202/1027746ar

\section{Aller au sommaire du numéro}

\section{Éditeur(s)}

UAAC-AAUC (University Art Association of Canada | Association d'art des universités du Canada)

\section{ISSN}

0315-9906 (imprimé)

1918-4778 (numérique)

\section{Découvrir la revue}

\section{Citer cet article}

Brandon, L. (2014). Double Exposure: Photography and the Great War Paintings of Frank Johnston, Arthur Lismer, and Frederick Varley. RACAR : Revue d'art canadienne / Canadian Art Review, 39(2), 14-28.

https://doi.org/10.7202/1027746ar

\section{Résumé de l'article}

Pendant la Première Guerre mondiale, trois artistes membres du futur Groupe des Sept - Frank Johnston (1888-1949), Frederick Varley (1881-1969) et Arthur Lismer (1885-1969) - ont utilisé le médium photographique pour créer des oeuvres dédiées au thème de la guerre. Johnston et Lismer n'ont jamais reconnu avoir utilisé la photographie dans leurs peintures de guerre, mais ont gardé certaines de leurs images sources dans leurs archives personnelles. Varley n'a conservé aucune photo de guerre et a rarement discuté publiquement de son usage de la photographie. De surcroît, ses biographes ont plutôt eu tendance à minimiser cet aspect de son travail et à hiérarchiser la peinture par rapport à la photographie. Le modèle se répète : après l'établissement du Fonds de souvenirs de guerre canadiens en décembre 1916, la photographie, malgré sa popularité, a été reléguée à un rôle secondaire de commercialisation visant à générer des revenus pour des commandes et des achats d'autres oeuvres d'art.
Tous droits réservés @ UAAC-AAUC (University Art Association of Canada | Association d'art des universités du Canada), 2014
Ce document est protégé par la loi sur le droit d'auteur. L’utilisation des services d'Érudit (y compris la reproduction) est assujettie à sa politique d'utilisation que vous pouvez consulter en ligne.

https://apropos.erudit.org/fr/usagers/politique-dutilisation/ 


\title{
Double Exposure: Photography and the Great War Paintings of Frank Johnston, Arthur Lismer, and Frederick Varley
}

\author{
Laura Brandon, Historian, Art and War, Canadian War Museum
}

\begin{abstract}
Résumé
Pendant la Première Guerre mondiale, trois artistes membres du futur Groupe des Sept - Frank Johnston (1888-1949), Frederick Varley (1881-1969) et Arthur Lismer (1885-1969) - ont utilisé le médium photographique pour créer des œuvres dédiées au thème de la guerre. Johnston et Lismer n'ont jamais reconnu avoir utilisé la photographie dans leurs peintures de guerre, mais ont gardé certaines de leurs images sources dans leurs archives personnelles. Varley n'a conservé aucune photo de guerre et a rarement discuté publiquement de son usage de la photographie. De surcroît, ses biographes ont plutôt eu tendance à minimiser cet aspect de son travail et à hiérarchiser la peinture par rapport à la photographie. Le modèle se répète : après l'établissement du Fonds de souvenirs de guerre canadiens en décembre 1916, la photographie, malgré sa popularité, a été reléguée à un rôle secondaire de commercialisation visant à générer des revenus pour des commandes et des achats d'autres œuvres d'art.
\end{abstract}

W hen noted British painter Augustus John (1879-1961) arrived on the First World War's Western Front in January 1918, he was overwhelmed by the unexpectedly new and rich subject matter. "Must have a Camera," he wrote to his wife and muse Dorothy (Dorelia) McNeill. ${ }^{1}$ While there is no confirmation he ever received a camera, or even took any photographs at the front, we do know from the visual evidence provided by other artists that during the First World War, photography was important in the construction of paintings for many artists, whether it was acknowledged or not. ${ }^{2}$ The technology, after all, had existed for seventy-five years and, following the introduction of the Kodak Brownie in 1900, was readily affordable. For many war artists, photography was a resource and a recording tool, a quick way of replacing or supplementing the traditional pencil sketch. For example, as British art historian Paul Gough notes in A Terrible Beauty: British Artists in the First World War, Edward Handley-Read (1870-1935) used photographs as the basis for a number of his war works, often from publications such as the Illustrated London News.3 Whether or not these artists were aware of the debates surrounding photography's verisimilitude and its status as an art form, they used it in a purely practical way: along with drawings and so-called "colour notes," photographs helped to document detail and refine composition.

The debates about the relative values of art and photography had emerged quickly following photography's invention in 1839, and continued into the early twentieth century, when Alfred Stieglitz (1864-1946) and others made it their mission to promote photography as an art form in its own right through exhibitions and magazines. ${ }^{4}$ Yet, at the time of the First World War, the majority of the public, including many artists, used and viewed the camera strictly as a recording tool, and their expectations for war photography were that it would render an unaltered image of reality. An important aspect of the debates related to Pictorialism. 5 This approach to composition relied on dramatic light effects, unfamiliar angles, and daring technical experimentation deployed in the service of romantic subject matter, centred on the fact that darkroom technology made it possible for fragments from individual photographs to be com- bined into a composite image. During the First World War, Australian official historian Charles Bean denounced official photographer Frank Hurley's (1885-1962) composite pictures as fakes. Lord Beaverbrook of the Canadian War Records Office (CWRO) had no such reservations. For him, as we shall see, reality could be constructed in this way if drawn from authentic source material. A composite battle picture, for example, was still a battle image. 6 Similarly, the paintings by the official war artists he employed such as Frank Johnston (1888-1949), 7 Arthur Lismer (1885-1969), and Frederick Varley (18811969), the subjects of this article, could draw on a variety of sources both photographed and sketched, providing the final product was convincing.

I am the Art and War historian at the Canadian War Museum (CWM), and my work is very much centred on material art history with a view to making the collections known. In consequence, my purpose with this article is not to address the theoretical debates surrounding photography or to explore deeply what photographers did or did not do during the war. Instead, I seek to reveal new links between publicly held photographs and artworks that shed light on the working practices of three well-known war artists and, in the process, illuminate these artists' attitudes to the medium of photography.

Although Johnston, Lismer, and Varley are the only Canadian artists represented in the CWM's First World War art collection whose work can clearly be associated with specific photographic material, a number of artists represented in this collection appear to have based their work on official photographs. They could have seen and purchased these in exhibitions, viewed them in military publications such as Canada in Khaki, or received them from the Canadian War Memorials Fund (CWMF, an arm of Beaverbrook's CWRO, which will be discussed later). These artists include J.W. Beatty (1869-1941), Vivian John Cummings (1875-1960), Louis Keene (1888-1970), James Kerr-Lawson (1864-1939), and William Nicholson (1872-1949). ${ }^{8}$ Because of the prevalence of the practice, it should come as no surprise that three of the future Group of Seven artists represented in the Museum's 
collection also made use of photography in their war art. However, the fact that Johnston, Lismer, and Varley made paintings traceable to specific photographs-Lismer even took his ownprovides a unique opportunity to explore the use of photography in war art, wartime artists' attitudes to the medium, and the subsequent history of the pictures that were the sources of their painted imagery.

I first learned about the use of photography by Johnston, Lismer, and Varley while I was conducting research on war artists in the CWM's photography collection. I was first interested in linking a number of official First World War photographs to artworks completed by both official and unofficial artists represented in the collection. But recently, it is the subject of this article that has become my prime focus. My work on Varley has been made possible thanks to the Museum's 6,800 official Canadian Expeditionary Force (CEF) photographs (originally in albums) that include copies of the prints Varley used for his paintings. 9 The Museum also holds Lismer's own wartime photographs. ${ }^{10}$ As for Johnston's, they were acquired by Library and Archives Canada (LAC) in 1997.11

Two of the artists-Johnston and Lismer-did not acknowledge their use of photography in their war work but kept some of their source images in their personal archives. Varley retained no war photographs and rarely discussed his reliance on the technology publicly. As we will see, his biographers have also tended to downplay this aspect of his work. This reserve surrounding Varley's use of photographic documentation may betray a certain unease with regard to the relationship between painting and photography.

\section{The First World War and Canadian Photography}

At the beginning of the First World War, Canadian soldiers were allowed to carry cameras with them while on active duty. 12 In early 1915, however, the authorities effectively banned the possession of such equipment by officers and their men as a matter of national security.13 In April 1916, the newly created War Records Office headed by Sir Max Aitken (who became Lord Beaverbrook in 1917) ${ }^{14}$ successfully petitioned the Canadian War Office for the right to allow official photographers to accompany the forces to the front lines. ${ }^{15}$ Ultimately three were appointed: Canadian serving soldier and engineer Harry Edward Knobel (1871-1955) covered the war for a few weeks from 28 April 1916, and British Daily Mirror employees William Ivor Castle (1877-1947) and William Rider-Rider (1889-1979) followed suit from August 1916 until November 1918. They were restricted as to where they could go, and their small number made it impossible for them to create a complete visual record of a war that saw more than 600,000 Canadians enlist and more than 60,000 die.
Beaverbrook's overarching goal for the CWRO was the creation of an archive, which came to include film, diaries, magazines, books, and art. ${ }^{16}$ For Beaverbrook, this evolving collection also served propaganda purposes through publications and exhibitions designed to promote positive views of the war in the interests of further enlistment, as well as financial and material support. It documented broadly shared views of the war as good for Canada and Canadians and worth fighting. Because practical and organizational challenges centring on the limited team of photographers and the nature of their equipment made comprehensive documentation-and propaganda productionvirtually impossible, Castle produced a number of composite images to fill some of the gaps and fulfill expectations, as we shall see below. ${ }^{17}$

Canada's official photographers worked with heavy equipment including glass plates (the eventual negatives) and often had to remain far from the action. Yet however cumbersome it was to take the photographs, the images could be quickly published in newspapers, magazines, and books, and exhibited for sale thanks to the relative rapidity of the developing process. ${ }^{18}$ The photographs included views of battlefields, ruins, soldiers at rest, the wounded receiving attention, officers, behindthe-lines encampments, and carefully tended temporary graves. They were displayed in a variety of dimensions in official exhibitions, including almost life size. They supported public impressions of the war as a relatively bloodless, often happy experience, successfully managed and leading towards victory. Corpses were generally absent and, indeed, rarely photographed. 19 The exhibitions were widely advertised; they toured extensively, in Britain especially, and were very popular. ${ }^{20}$ The first exhibition of Canadian war photography, which opened in London in December 1916, was so successful that it then travelled in Canada and the United States for two years. Here, the propagandistic aims of the images were never straightforwardly acknowledged; instead, their verisimilitude and indexical quality were underscored. They afforded "[T]hrills as if one were on the battlefield itself," as the London Daily Mirror reported in July 1917. According to the final 1919 exhibition souvenir catalogue, millions visited the touring displays between 1916 and 1919.21

As Canada's official photographers with privileged access to the battlefields, Ivor Castle and William Rider-Rider were prominently featured in these exhibitions. Castle was a master of composite photography, creating, for instance, a series of pictures of men going "over the top" (i.e., climbing out of their trenches) during the Battle of the Somme.22 Rider-Rider found Castle's practice objectionable. He claimed these "Somme" photographs had been made at a trench mortar school outside Saint-Pol, France, and had been falsified. He was right. 23 The printed pictures are in fact composites. Castle's 


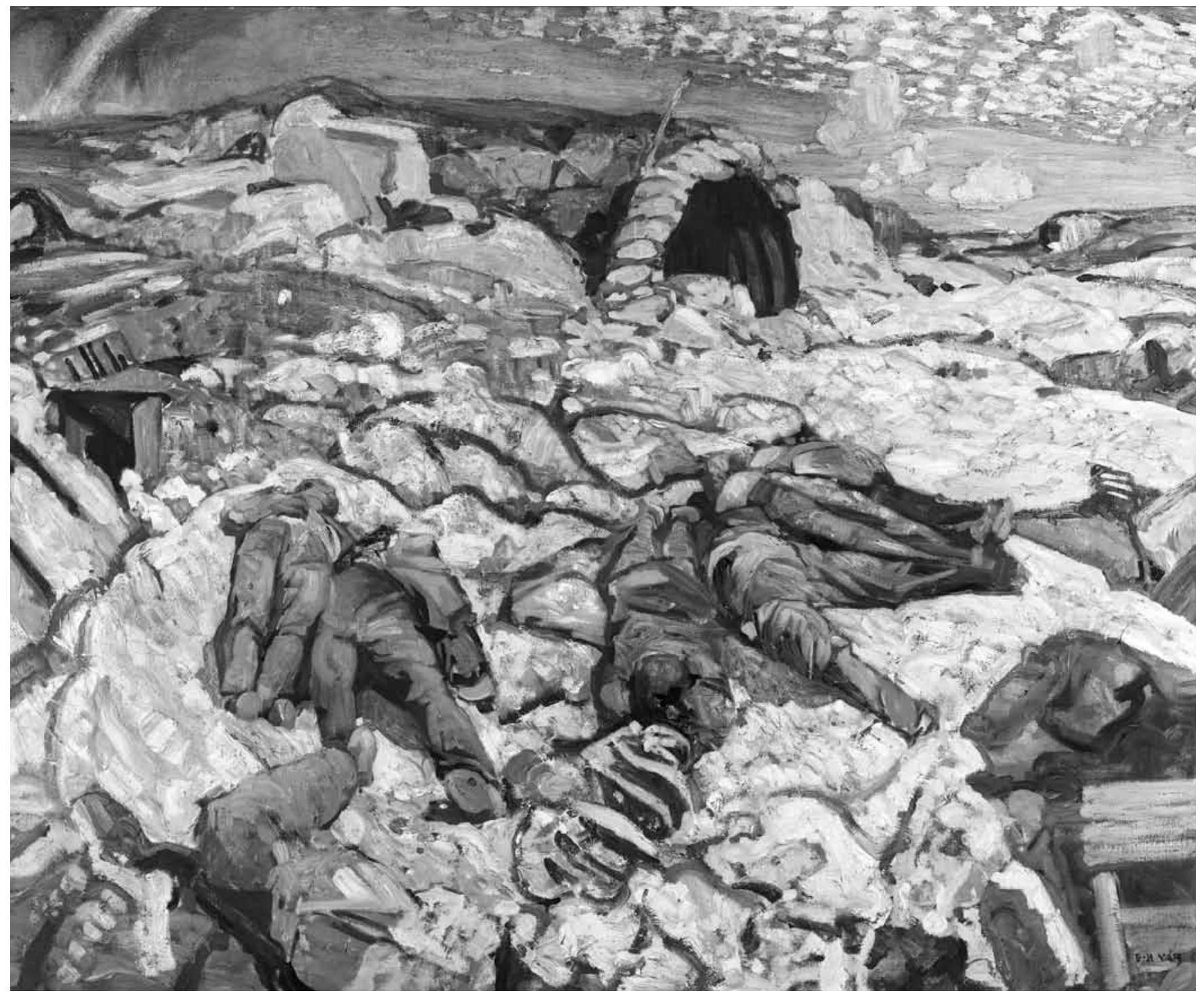

Figure I. Frederick Varley, The Sunken Road, 1919, oil on canvas, 132.7 × 162.7 cm, Canadian War Museum, Beaverbrook Collection of War Art, 19710261-077I.

original negative for one of the images shows that one soldier still has the canvas breech cover on his gun and there is no smoke. In contemporary published prints derived from this negative, the gun is missing and smoke has been added to create the illusion of battle. ${ }^{24}$ But despite Rider-Rider's misgivings, the public remained in the dark, and a composite photograph by Castle entitled The Taking of Vimy Ridge became the highlight of the second exhibition of Canadian war photographs, which opened in London in July 1917, only two months after the important Canadian victory at Vimy Ridge. Printed in a massive format (3 36 metres), it could be purchased for the sum of
$£ 120$ (approximately $£ 7,000$ today). More than any other Canadian First World War photograph, this one reveals the degree to which the authenticity of the photographic document could be overlooked when an expectant public was provided with an image that met its assumptions for the depiction of such a significant battle. 25

The Taking of Vimy Ridge is made up from parts of three battlefield negatives, two of which have been identified. The first shows the explosions in the sky; the second, a shell half-buried in the ground, behind which soldiers crossed the pock-marked battlefield; and the third, two rather peaceful- 
looking dead bodies lying in a churned-up landscape with soldiers in the distant background. The only feature that betrays the manipulation is the scale of the corpses, which are too large in relation to the figures crossing the battlefield behind them.

\section{Painting the War}

A decisive event led Beaverbrook to shift away from photography as the main tool for building his war record and to turn toward paintings and graphic arts: the horrific Second Battle of Ypres in April and May 1915, which saw Canadian forces outnumbered, outgunned, outflanked, and decimated by the Germans' first use of poison gas. The attack resulted in 6,000 Canadian casualties over four days. ${ }^{26}$ Because of the recent ban on photography, the event was not documented. Therefore, in November 1916, Beaverbrook commissioned a large painting from the British artist and illustrator Richard Jack (1866-1952) through the CWMF.27 If composite photographs were not problematic for Beaverbrook or the general public, neither were paintings that drew from a variety of sources. Jack's reconstruction of the battle, loosely based on soldiers' memories and other first-hand accounts, shows a wounded young man standing facing the enemy and encouraging the remaining soldiers to fight on. Beaverbrook was pleased with the result, and the positive experience of fruitfully working with a painter contributed to his decision to commission more artists to record Canada's war experiences for posterity. Photography at the time was relegated to the secondary role of generating funds through exhibitions and sales; black and white pictures of the kind discussed above were to finance the making and acquiring of artworks. Of course, these photographs also remained available as source material for paintings.

Of the Canadian artists hired by Beaverbrook for the CWMF, some were already serving as soldiers, while others were recruited. ${ }^{28}$ Frederick Varley was one of four painters given a temporary commission with the rank of captain. While some artists were assigned to specific units, Varley had more freedom to circulate behind the lines. ${ }^{29} \mathrm{He}$ accompanied the troops from August 1918 until the end of the war on 11 November as they advanced rapidly from Amiens, France, to Mons, Belgium, in the last Allied offensive, known as "The Hundred Days." Frank Johnston and Arthur Lismer's commissions, on the other hand, came from the National Gallery of Canada (NGC), which ran Beaverbrook's scheme on the home front. Lismer, hired in 1918 to record wartime activities in Halifax, Nova Scotia, produced vibrant depictions of dazzle-painted ships in the harbour. ${ }^{30}$ Johnston similarly worked for several months documenting pilot training at various air bases in Ontario in 1918. ${ }^{31}$ His watercolours of Curtiss JN-4 aircraft joyously looping-the-loop above

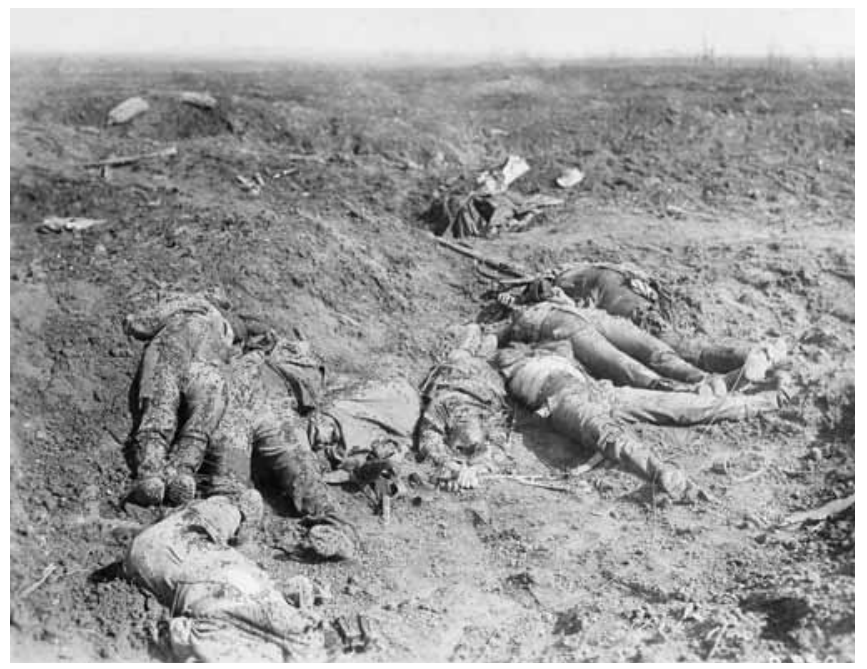

Figure 2. William Ivor Castle, The Battlefield after a Canadian Charge, October 1916, Canadian War Museum, George Metcalf Archival Collection, 19920044-84I (formerly catalogued as Canadian Expeditionary Force album photograph, O-940).

the tranquil fall countryside uniquely convey the idea of flight. For all three, the relationship between what they painted and the photographs they utilised seems to have been mainly indexical. For specific subject matter in their compositions-corpses, ships, and aircraft, for example-that they had not adequately recorded in sketches, black and white images of this material provided an important resource.

\section{Frederick Varley}

The association between Varley's celebrated painting The Sunken Road (fig. 1) and an official CEF photograph was first made public almost fifty years after he painted it, when author Peter Mellen identified "Photograph of the Dead, used as a study for The Sunken Road, c. 1918" as a main source for the painting (fig. 2). 32 This is not entirely accurate; while the German bodies depicted in this photograph were incorporated into the painting, Varley's main source was actually an oil sketch of his own from which bodies are entirely absent. ${ }^{33}$ According to historian Maria Tippett, the composition was conceived in 1919 during Varley's second trip to the Front. By this time the war was over and the dead would have been buried. ${ }^{34}$ Before then, however, it is likely he would have seen some body parts, but rarely entire corpses, which were swiftly buried. By comparing the painting and the aforementioned photograph, Tippett establishes beyond doubt the relationship between the two images; the dead bodies are shaped and arranged in identical ways. 35 But 


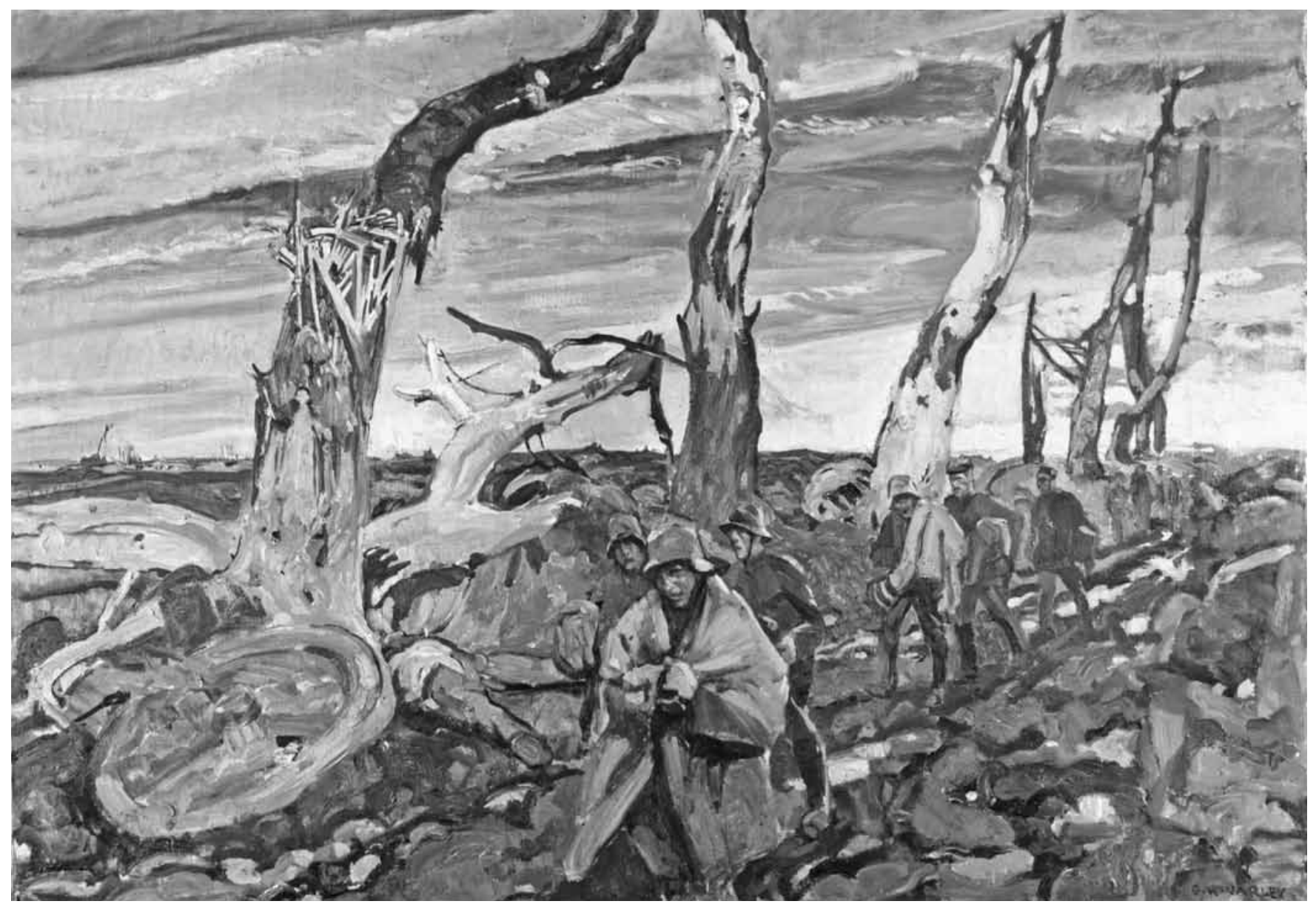

Figure 3. Frederick Varley, German Prisoners, c. 1919, oil on canvas, $127.4 \times 183.7 \mathrm{~cm}$, Canadian War Museum, Beaverbrook Collection of War Art, 19710261-0807.

in translating the black and white photograph to colour, Varley has added splashes of red to suggest gaping wounds and the flow of blood. As Tippett points out, the artist did choose (although he later denied this) to tone down some of the most shocking detail of his source- the decapitated bodies—considering such subjects "horrid." 36 These, while clearly visible in the photograph, are much harder to discern in the painting, having been fused into areas of impasto paint that meld the corpses and war detritus together.

Tippett clearly sources the photograph to LAC and provides its correct title, The Battlefield after a Canadian Charge. 37 Dated October 1916, this photograph predates Varley's arrival in Europe by two years and therefore bears only a tangential relation to what the painter actually observed and sketched. The reason the connection between the photograph and the painting was not made for fifty years is presumably because the photo- graph had been censored. Indeed, it is clearly marked "Not for sale or reproduction" in the CWM album. ${ }^{38}$ This restriction was most likely due to its particularly gruesome depiction of grievously wounded bodies, a subject generally avoided in war art and photography.

Varley reused part of the same photograph in another major war painting, German Prisoners (fig. 3). Its composition is based on a small watercolour made on his second trip to the continent, representing a landscape with trees, but no figures. 39 The corpse found at the right of the source photograph is depicted below a tree, on the left side of the painting. German Prisoners also draws on a CEF photograph, this one of German prisoners, taken near Monchy-le-Preux in France in 1918 (fig. 4). Even though he has drastically reduced their number, Varley has clearly borrowed the walking figures in his painting from the photograph. 
Varley always combined his use of official photographs as source material with sketches made in situ and recollections of scenes that he recorded in letters to his wife and others. ${ }^{40}$ Indeed, his biographer, Maria Tippett, argues he personally witnessed what he depicted in German Prisoners: "his encounter with a group of bedraggled, war-weary German soldiers provided him with the subject." 41 Describing Varley's use of the CEF photograph for The Sunken Road, she adds, "Seeing a group of corpses and gun pit and studying a CWRO photograph of the remains of a German machine-gun crew resulted in his most powerful post-war painting." 42 Varley had claimed as much in a 1960 interview with journalist Lawrence Sabbath. ${ }^{43}$ Indeed, his war paintings function as composites of a sort. They are amalgams of scenes the artist personally witnessed and of available photographs documenting events that he might not have seen, but that complemented what he had observed. All this was filtered through a tremendous sense of outrage at what the war had wrought. As he wrote to his wife:

You in Canada...cannot realize at all what war is like. You must see it and live it. You must see the barren deserts war has made of once fertile country...see the turned-up graves, see the dead on the field, freshly mutilated-headless, legless, stomachless, a perfect body and a passive face and a broken empty skull-see your own countrymen unidentified, thrown into a cart, their coats over them, boys digging a grave in a land of yellow slimy mud and green pools of water under a weeping sky. You must have heard the screeching shells and have the shrapnel fall around you, whistling by you-Seen the results of it, seen scores of horses, bits of horses lying around, in the open-in the street and soldiers marching by these scenes as if they never knew of their presence-until you've lived this...you cannot know. ${ }^{44}$

\section{Arthur Lismer}

When Lismer accepted his June 1918 commission, his letter of authority from the military stated that he was "permitted to make drawings and sketches of the shipping and war activities, Halifax, for the War Records Office. You are not permitted to make sketches, paint, or take photographs of the fortifications." 45 Although the allowed activities do not specifically include photography, it seems to have been implied in the sentence about forbidden subject matter. From this, it can be deduced that the authorities anticipated that artists sketching in an official capacity on the home front would use cameras when going about their work and, indeed, Lismer did. He was a keen camera user and had set up a darkroom in his bathroom. 46 Lismer's use of photography, however, was closely bound with his painting practice. In preparation for paintings, he would

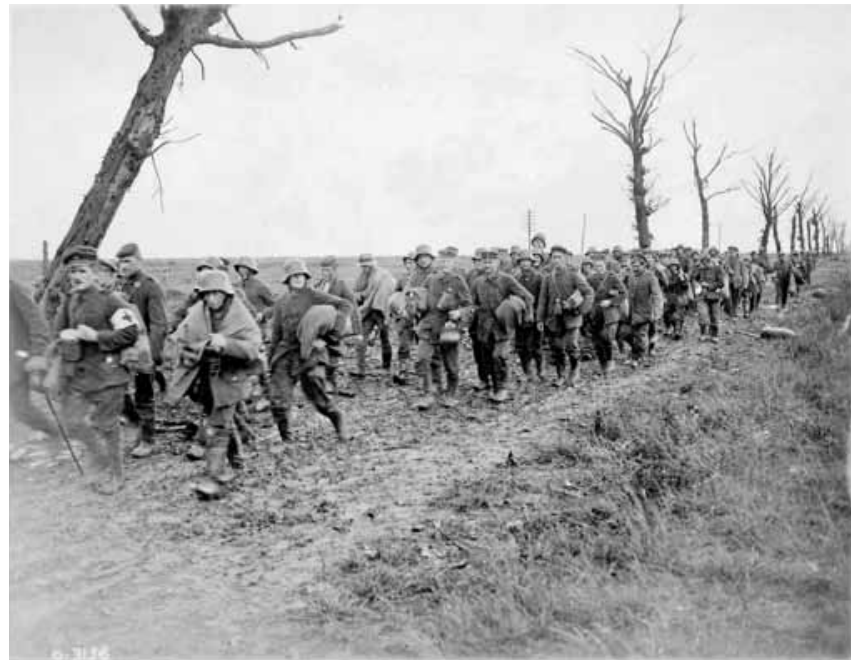

Figure 4. Unidentified photographer, Advance East of Arras-German Prisoners Taken near Monchy, August 1918, Canadian War Museum, George Metcalf Archival Collection, 19930012-586 (formerly catalogued as Canadian Expeditionary Force photograph O-3136).

take pictures of his daughter Marjorie playing on the Halifax shore, for instance, as often as he drew her. Similarly, he was as likely to photograph the vessels that docked in Halifax harbour as he was to sketch them. Since he both photographed and sketched, these activities were bound to find their way into his finished paintings. Nevertheless, Lismer identified himself as a painter and printmaker. Ultimately, photographs seem to have acted mainly as useful source material in his artistic practice and as family memory keepers.

Lismer's well-known "dazzle" painting Olympic with Returned Soldiers (1919) is composed from a rich mix of personal photography, picture postcards, small sketches, and studies in pencil and watercolour, almost all fortuitously kept after his death by his daughter Marjorie Bridges (fig. 5). ${ }^{47}$ The Olympic was a magnificent vessel and a sister ship of the Titanic, which had sunk seven years earlier. The Olympic ferried troops to and from Europe throughout the war and, to avoid being sunk by submarine attack, was decorated after April 1917 with at least two dazzle schemes. ${ }^{48}$ Dazzle was a form of painted camouflage. Its complex patterns of geometric shapes in contrasting colours were understood to make it more difficult for the enemy to target ships with any degree of accuracy. This type of concealment work had been developed by artists such as Franz Marc (1880-1916), André Mare (1885-1932), and Edward Wadsworth (1889-1949), who were familiar with the expressionist and cubist art from which its decorative form derived. As a major wartime port, Halifax saw the arrival and 


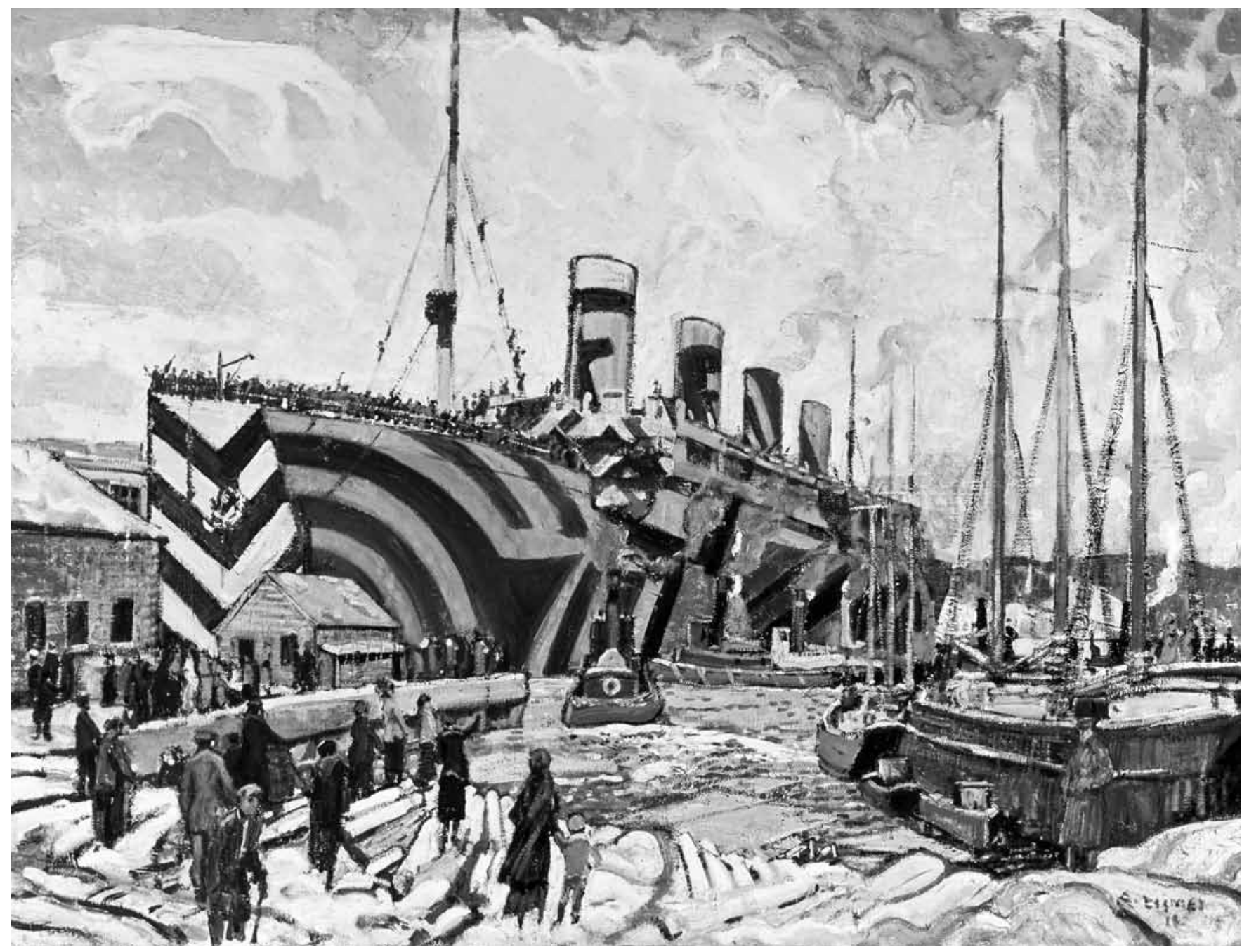

Figure 5. Arthur Lismer, Olympic with Returned Soldiers, 1919, oil on canvas, $123 \times 163.3 \mathrm{~cm}$, Canadian War Museum, Beaverbrook Collection of War Art, 19710261-0343.

departure of many dazzle-painted ships. The colourful patterns and criss-crossing lines made this an appealing and painterly subject matter for a modernist like Lismer, and he included dazzle in a number of his wartime compositions.

But in 1919, when Lismer painted the Olympic, the vessel ferrying returning soldiers was not decorated. By February 1919 , she had been returned to her peacetime appearance. So what was Lismer's source for her decoration? From the beginning of his commission in June 1918, the artist had sketched dazzle ships on a number of occasions. Several drawings bear a certain resemblance to the Olympic, even though they are not identified as such. ${ }^{49}$ Furthermore, picture postcards of dazzlepainted vessels taken by the renowned Halifax photographer
Wallace R. MacAskill (1887-1956) were widely available for sale at the time. In his account of the story of the Olympic, David Gray includes an unattributed picture postcard of the vessel, dressed in the same dazzle that is seen in Lismer's painting. Such documents might have served as additional sources. 50

Lismer's painting of the Olympic is clearly a composite, its imagery drawn from sketches, printed matter, and pictures. An obvious compositional source is a picture postcard of the Aquitania from his collection (fig. 6).51 The similarity is startling if the vessel's very different dazzle scheme is overlooked. One photograph attributed to the artist that bears a close compositional relationship to the finished work is of an unadorned ship, which does not show the dramatic zigzag pattern in black, white, and 
blue (fig. 7). Furthermore, it displays only two funnels, whereas the Olympic had four. Another Lismer photograph shows the Olympic docked in precisely the same place as the two-funnelled vessel (fig. 8). Here, the ship is festooned with bunting from bow to stern. In the final painting, however, Lismer forgoes this decoration and, instead, integrates the two-funnelled vessel's small foremast into his composition, festooning its rigging with bunting instead. Possibly using the picture postcard of the Aquitania, Lismer reworked the tugboats for his painting. The crowd of people on the foreshore may have been inspired by another of his photographs of the Olympic.52 A number of preliminary drawings show how the artist worked out the details of his composition from this array of sources. 53 While the photographs he took himself were clearly important to his artistic process, he never once exhibited them. Like the picture postcards, he most likely saw them as documentary material and not artworks in their own right.

\section{Frank Johnston}

As a CWMF commissioned artist, Johnston received permission from the military in July 1918 to sketch part-time at the Royal Flying Corps (RFC) schools in and around Toronto. Flight instruction, generally in the bi-winged Curtiss JN-4, was first carried out at Camp Borden, Ontario, and later extended to other training facilities. Within a few months of receiving his commission, Johnston gained some knowledge of flight as a passenger in a two-seater training aircraft, an experience that required considerable nerve on his part. "Flying... is a very fine sport with the exception of the spinning nose dive," he observed, with perhaps intentional understatement about this death-defying manoeuvre. ${ }^{54}$ None of the extant documentation indicates whether Johnston was given any instructions as to what he should depict. In general, he found what he saw in the training camps to be new and unfamiliar, and it compelled him to develop different ways of painting, primarily by making use of photography. As he wrote in a letter to NGC Director Eric Brown on 2 August 1918, "The subject is one that requires rather careful consideration and is a difficult one to get any pictures out of as there is little or no action in the training camps other than straight flying." 55 The approximately fifty small black and white photographs in LAC's Mary Bishop Rodrik and Franz Johnston fonds show how Johnston solved the problem of dramatizing scenes that were challenging to capture in sketches. 56 In her essay "Picturing the Great War: Frank Johnston's RAF Paintings and the Authority of the Photographic Record," Shana Faust demonstrates that half of the seventy-three paintings Johnston produced under his war commission correspond directly to these photographs. 57 A Johnston painting of Camp Borden, for example, is barely distinguishable in composition

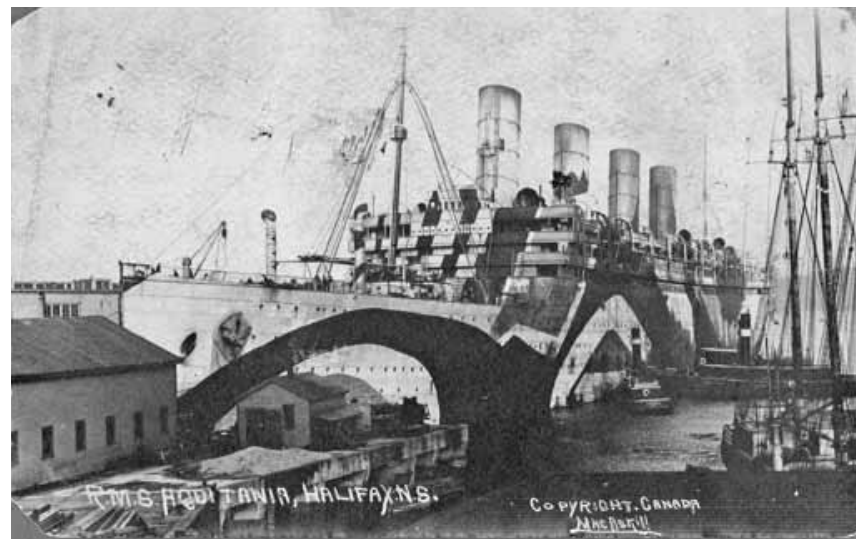

Figure 6. Wallace R. MacAskill, R.M.S. Aquitania, Halifax, N. S., undated picture postcard, Canadian War Museum, George Metcalf Archival Collection, Arthur Lismer fonds, 1979005I-002.

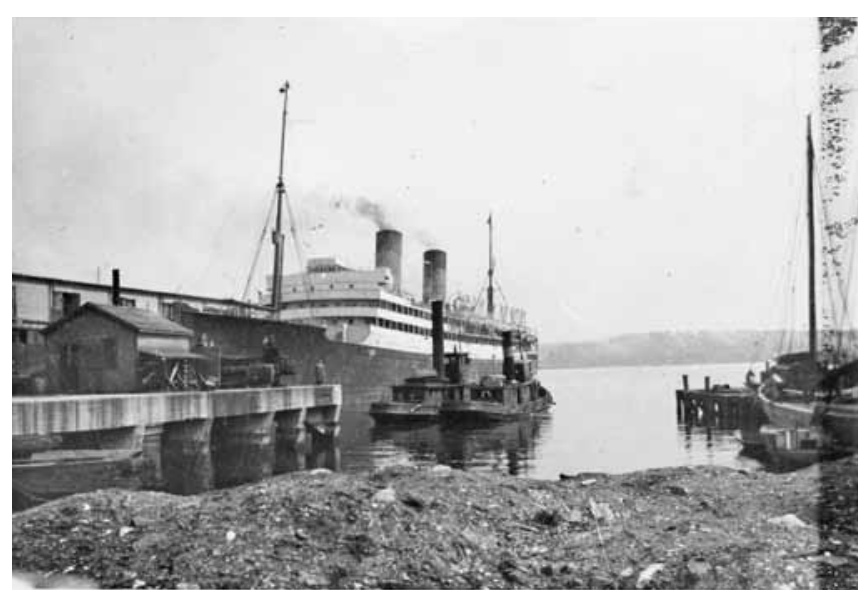

Figure 7. Arthur Lismer, An Ocean Liner Moored in Halifax Harbour, c. 1918-19, photograph, $12 \times 17.5 \mathrm{~cm}$, Canadian War Museum, George Metcalf Archival Collection, Arthur Lismer fonds, 1979005I-0I7.

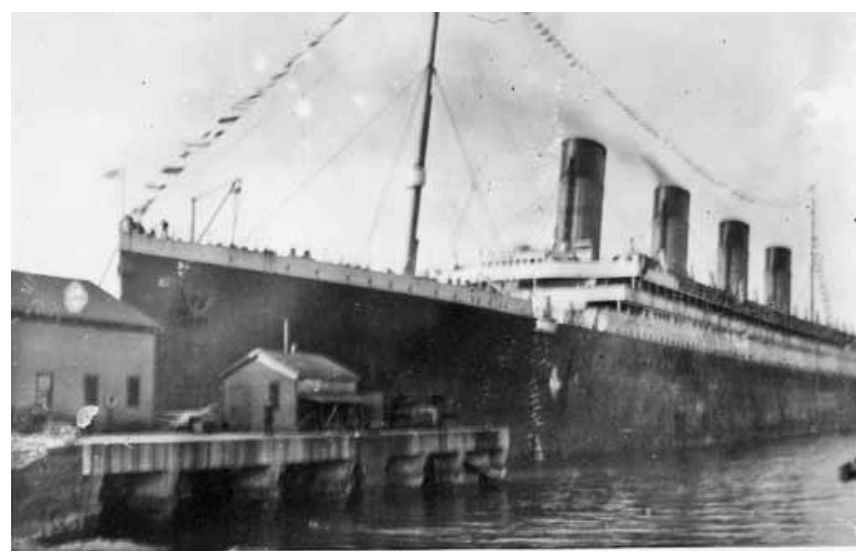

Figure 8. Arthur Lismer, The R.M.S. Olympic Moored in Halifax Harbour, c. 1918-19, photograph, $12 \times 17.5 \mathrm{~cm}$, Canadian War Museum, George Metcalf Archival Collection, Arthur Lismer fonds, 1979005I-021. 


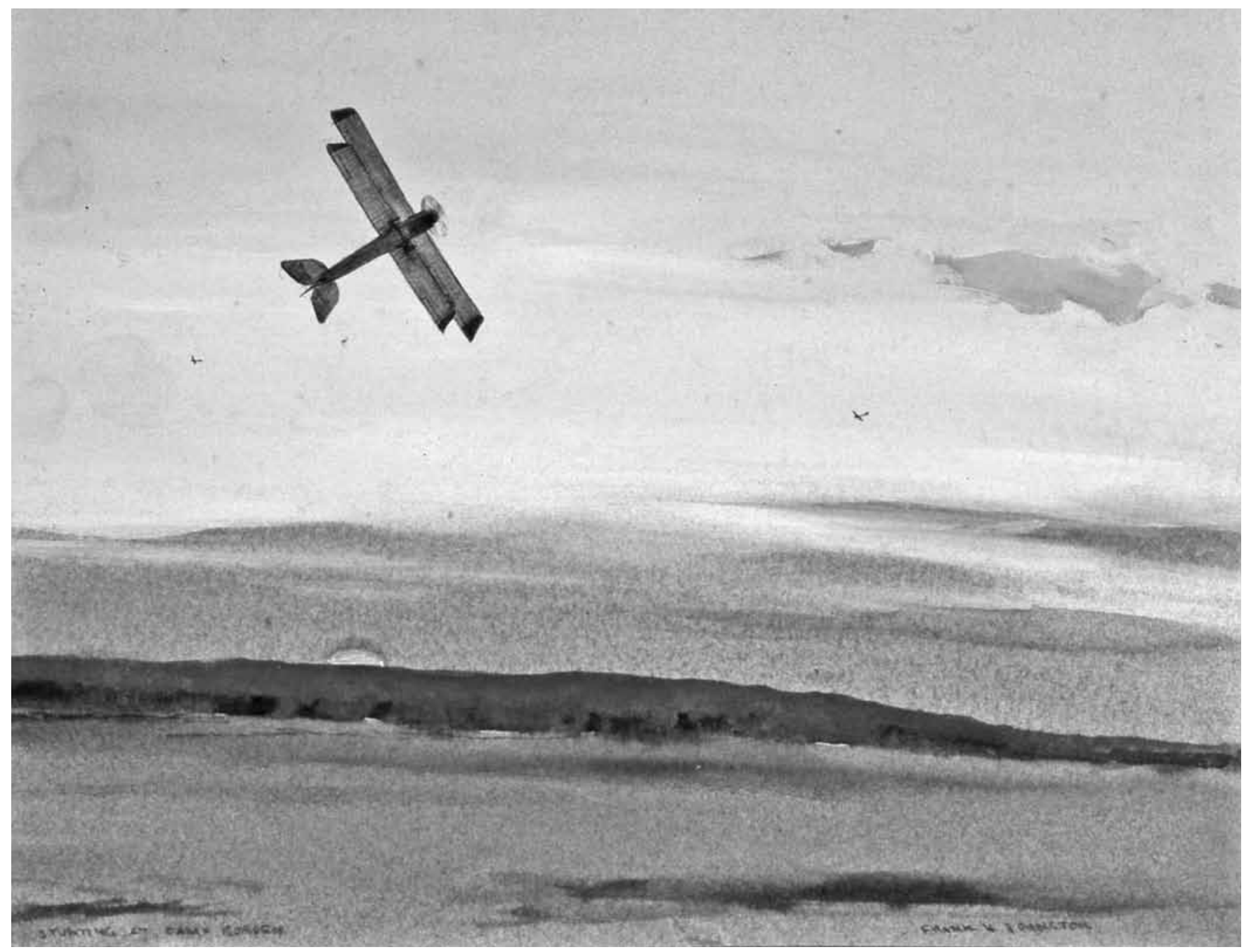

Figure 9. Frank Johnston, Stunting at Camp Borden, undated, watercolour and gouache on art board, $28.4 \times 35.8 \mathrm{~cm}$, Canadian War Museum, Beaverbrook Collection of War Art, 19710261-031I.

from an anonymous photograph preserved in the fonds. Also of note, perhaps for their close resemblance to two of the collection's photographs, are Stunting at Camp Borden and Taking Off (figs. 9-12). According to Faust, the photographs Johnston used (and kept) were not his own; they were taken by trainee pilots between 1917 and 1918.58

Fascinated by flight as a subject for art, Johnston soon found it "more or less impossible to do the subject justice in spare hours." 59 He successfully requested a two-month fulltime contract beginning in late August. In fact, his commission would continue until 14 March 1919 and see him sketch at flight training schools at Camp Borden, Leaside, Deseronto, and Long Branch, Ontario. For this work, he received a total payment of $\$ 3,000$, an essential income to compensate for the impossibility of undertaking other money-producing activities. The fact that his approach varied little over the course of his commission suggests that the CWMF's Canadian officers were well pleased with his watercolour, gouache, and pastel on paper compositions. Their brilliant colour and spectacular landscape and skyscape format met with approval, in part perhaps because none of them alluded to the appalling destiny of the war-bound pilots. Only one non-combat accident provided an opportunity for a dramatic composition. A Tragic Incident depicts an aircraft at the moment it is struck by lightning. 60

If Johnston excelled at painting aerial views of the Ontario landscape, he seems to have struggled with aircraft, a very 
new subject for him. Accuracy was thus often achieved by the careful copying of photographic images, resulting in a certain static model-like quality in the finished compositions. His use of photography therefore went a little further than that of Varley and Lismer, who treated such imagery mainly as a starting point or memory aid, not as a basis for exactitude. Nonetheless, he shared their view of it as source material for paintings. Explaining what he saw as photography's role relative to painting, in his undated brief essay "Notes on War Art," Johnston writes, "A camera 'records' but a painter 'interprets." 61 This statement makes it clear that he understood painting as a more complex activity than photography. For him, a recorded image was a copied image, whether it was from a photograph or from actual sight. Painting was different; its role was to develop meaning by organizing the seen or photographed motifs into an evocative, if not dramatic, composition that was more than a record.

Faust, however, believes that Johnston took his use of photography further than simply to copy aircraft. She argues that by exploiting "characteristics of the photographic print such as perspective, clarity, a flat finish, and cropping" Johnston deliberately drew from the indexical qualities he attributed to photography to provide authenticity for his war work. ${ }^{62}$ For example, she argues that, in addition to its aerial perspective, the lack of overtly visible brushwork and the compression of the view brought about by the even tonality and hues of the work contribute to a photographic quality in a canvas such as As It Looks over the Side. ${ }^{63}$ Furthermore, Faust contends that Johnston was being strategic when he pursued an approach to painting that made his works look like photographs. For him, she maintains, the closer his paintings were to black and white images of the same subjects, the more truthful they would appear to be. She supports her argument in two ways. First, for Johnston the very fact that the flight schools required the pilot trainees to take photographs meant that these held some kind of indexical authority, even if the schools' intention for these images might have been something entirely different. Second, by pursuing photographic likeness in his work through the use of RFC material and by giving his artworks factual titles relating to place and date, Johnston attempted to establish the institutional legitimacy of his work.

While there is merit to Faust's argument, it is at odds with what Johnston wrote about photography in his "Notes," in which he made no such claims. In this context, Faust's particular conception of indexicality raises the possibility that the more subtle photographic effects she believes Johnston to have deliberately exploited may simply have been the result of his literal transference of the photographic image to the canvas. In coming to her conclusion, Faust draws on a body of more recent scholarship that views photography as an infinitely more com-

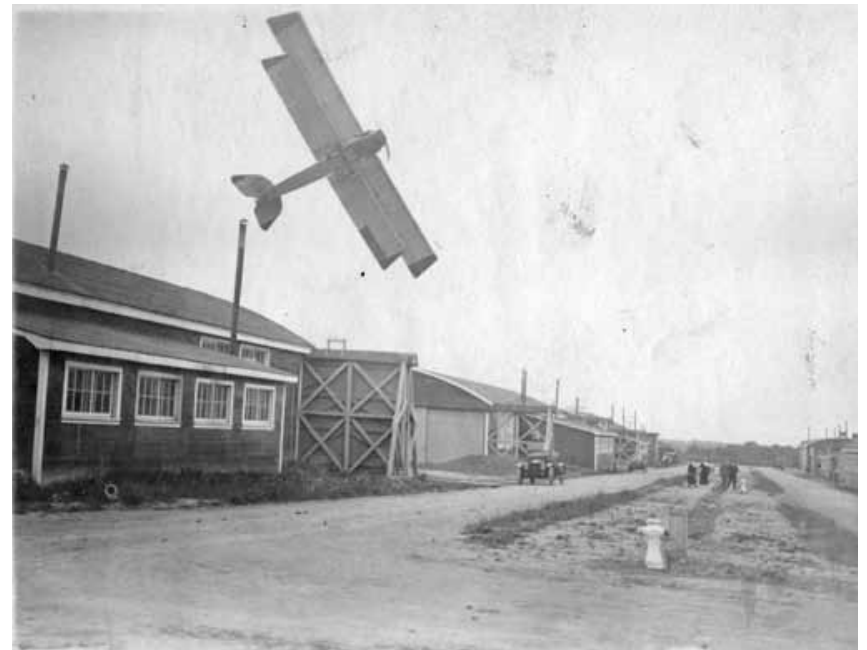

Figure 10. Unidentified photographer, Bi-plane banking over Barracks, Library and Archives Canada, Mary Bishop Rodrik and Franz Johnston fonds, R 320-0-4-E, Franz Johnston photographs, Mikan no. 4558358.

plex creative medium than an artist like Johnston likely would ever have imagined it to be. In so doing, she points to the dangers of presentism when examining the relationship between art and photography a century ago. Nevertheless, the direct links between half of Johnston's paintings and the photographs that Faust identifies do demonstrate that the artist lacked confidence in depicting aircraft. Furthermore, he kept the photographs from which he copied these machines. One can imagine that at the time the black and white images may have served to authenticate his subjects should his employers have asked questions. Flying was, after all, a relatively new pursuit and an experience unknown to many.

Beyond the requirements of his commission, however, Johnston acknowledged on record, though admittedly near the end of his career, that his task as a painter was to interpret what he saw. Thus, in a painting such as $A$ Tragic Incident his task was clearly a dual one- to be accurate in his depiction of the aircraft, which he "saw" with the help of photography, but imaginative in his rendition of the drama of this aircraft being struck by lightning. Here, the aircraft is painted with exactitude, but the stormy sky and the bravura flash of lightning that strikes it do not share the same adherence to accuracy and are painterly. Like the paintings of his fellow artists Varley and Lismer, Johnston produced a composite. 


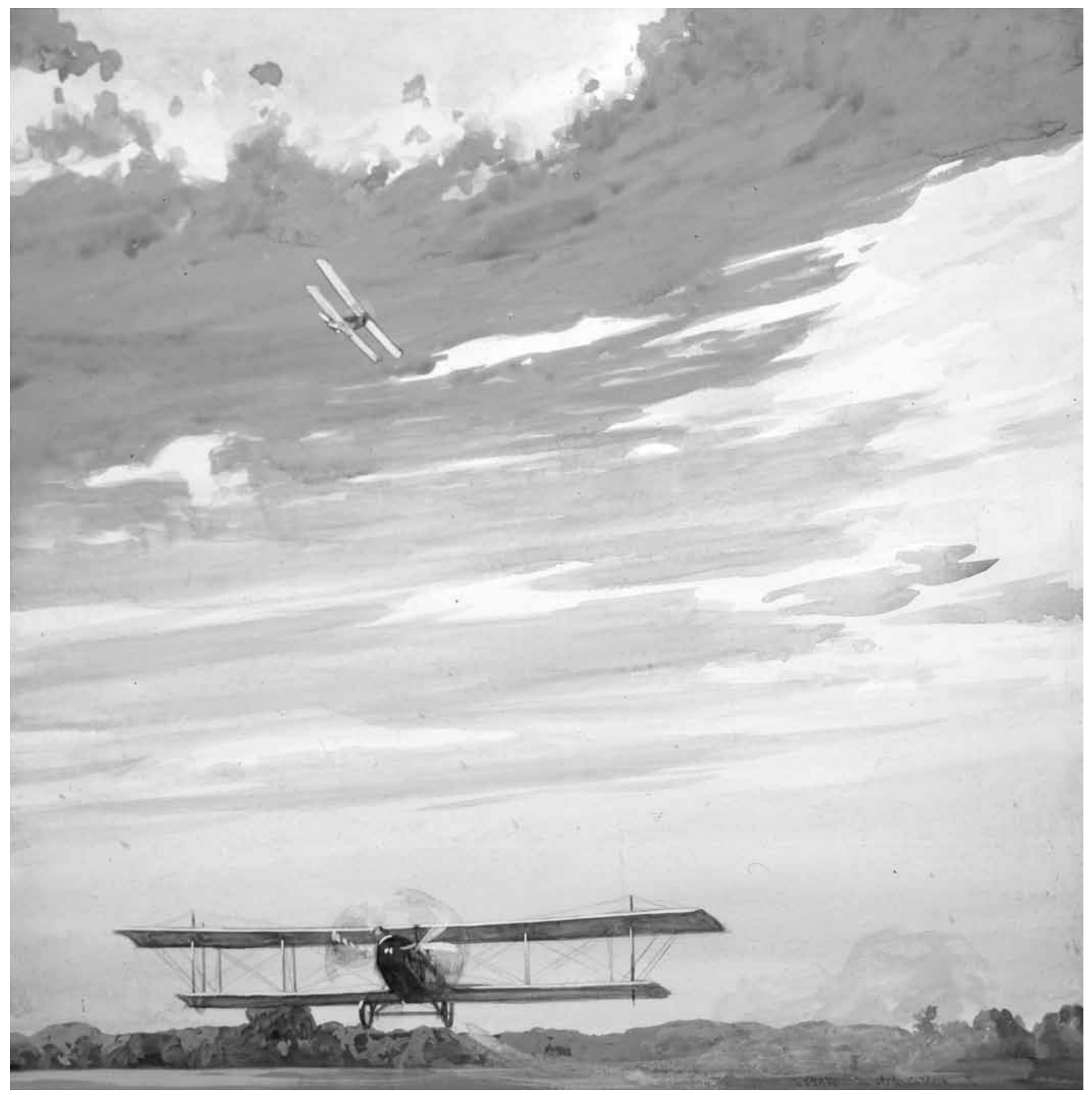

Figure II. Frank Johnston, Taking Off, 1918, watercolour and gouache on art board, $37.4 \times 37.3 \mathrm{~cm}$, Canadian War Museum, Beaverbrook Collection of War Art, 19710261-0298. 


\section{After the War}

The history of the photographs used by Varley, Lismer, and Johnston in their paintings sheds light on the relationship of the two media in the twentieth century. The picture of dead German bodies that Varley used for the two paintings discussed above was not preserved in his personal archive. CWM and LAC each acquired at least one copy after the war, ${ }^{64}$ but no connection between this image and his paintings can be traced through their search engines, perhaps because the image has never been widely published, having been censored during the war. At both institutions, it is also part of a massive fonds of some seven to eight thousand official First World War photographs that now primarily serve a documentary purpose for First World War historians. The marginalization of this source document is highlighted by the rather different fate of Varley's sketches for the two works. The one that served as a starting point for The Sunken Road remained in the artist's hands, ultimately finding a home in the Art Gallery of Ontario. The one for German Prisoners is in the National Gallery of Canada. The fact that Varley's source material for his war paintingsboth photographic and sketched-was not kept together owes much to the artist's postwar peripatetic lifestyle and to the fact that he was often in ill health and struggling financially, selling paintings whenever he could. Keeping an archive of any kind together in such circumstances would have been impossible. Furthermore, as I have noted, Varley never made any specific comment on photographic material having contributed to his compositions. Indeed, he is reported to have said in 1960 that the source of The Sunken Road was to be found in his war experiences and in seeing dead bodies. ${ }^{65}$ It was only in 1970 that Peter Mellen proposed that Varley in fact did use a photograph. Mellen seems almost embarrassed to mention it; he writes apologetically that its use "does not detract from his [Varley's] work, but demonstrates how Varley was able to go beyond the photograph to make a powerful statement about the war." 66 Would a more positive statement have made further exploration of Varley's wartime use of photography possible? In 1970, probably not. The globally unpopular Vietnam War (1959-75) was then raging, and within a year the National Gallery of Canada had transferred Varley's war paintings to the CWM as documents of war like the photographs on which they drew, ensuring some degree of oblivion for both. 67

Lismer and Johnston's photographic sources are now archived. However, the finding aid for Johnston's material produced in 1998 by LAC covers textual material only. Upon last enquiry (2012), the photographs had not yet been catalogued. A number of explanations can be offered. First, the photographs are not Johnston's. Indeed, no authorship or provenance can be assigned to any of them. Second, although at least two exter-

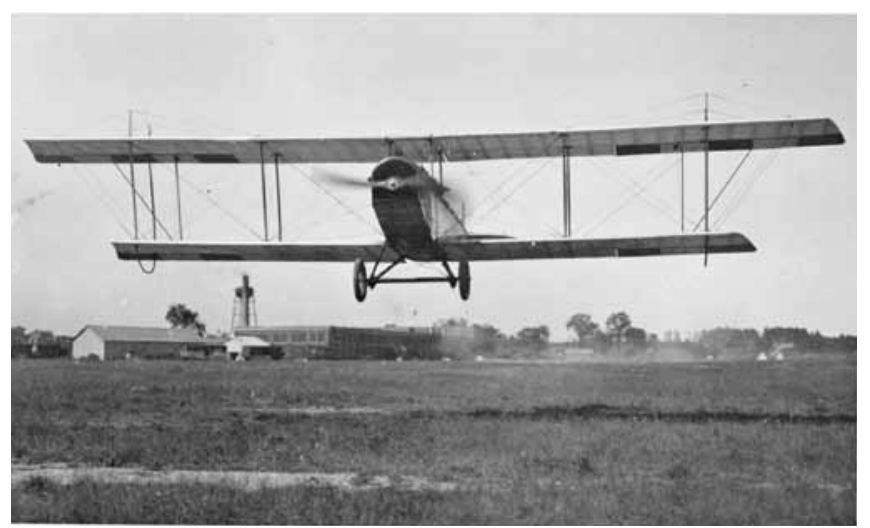

Figure 12. Unidentified photographer, Bi-plane, Library and Archives Canada, Mary Bishop Rodrik and Franz Johnston fonds, R 320-0-4-E, Franz Johnston photographs, Mikan no. 4558357.

nal researchers (Shana Faust and I) have mined them for their use as source material for his war paintings, this connection is not sufficient to necessitate a finding aid for the photographs. But even if LAC values these photographs less than the textual fonds, clearly Johnston saw them as a crucial part of his artistic process. In contrast to Varley, he did keep them with his archive, as did his descendants.

The postwar history of Lismer's photographs is also interesting. Upon receipt, CWM immediately catalogued them as part of a collection of wartime material that included sketchbooks given by Lismer's daughter to the museum. Her correspondence with the museum makes it clear that the photographs were donated because of their connection to her father's war art. ${ }^{68}$ If she valued them, her father certainly did too; contrary to the case with Johnston, these were Lismer's own photographs. Their authorship is most likely one of the reasons the museum came to consider them as a particularly significant acquisition and catalogued them accordingly.

\section{Conclusion}

The First World War production of Frank Johnston, Arthur Lismer, and Frederick Varley provides an important case study for the intricate relationship between war art and photography nearly a hundred years ago. For all three, the link was entirely indexical. Pictures of ships, aircraft, and corpses provided images that they could not accurately source from their own sketches and memories, and assisted in the realization of compositions. Although he claimed to have seen such scenes, Varley recognized that corpses lifted from censored official images to which he had privileged access added significant drama 
to the finished canvases he created based on his own corpse-free battlefield sketches. Johnston found that photographs of aircraft in flight taken by trainee aviators as part of their course work offered a level of heightened accuracy that he could not capture himself when sketching from the ground. For Lismer, his own photographs and commercially available picture postcards provided details he had not sketched, as well as entire compositional frameworks. These artists' use of photography was not entirely hidden; yet, at the same time, none of the three acknowledged their usage publicly in their lifetimes. Johnston's and Lismer's photographic source material remained unknown outside their families until after their deaths. Given the violence of the photograph of corpses he used for The Sunken Road and German Prisoners and its usage restrictions, Varley may have handed his source image back to the authorities or destroyed it. The other photograph he used for German Prisoners includes no such restriction against public use and could have been retained. In the final analysis, we simply do not know why either photograph disappeared from his archive. All we know is that when Varley's first biographer linked the powerful iconography in Varley's The Sunken Road to a photograph, his grudging acknowledgment of this evidence clearly indicated that in his opinion the painted version was superior to the original image, thus elevating painting above photography. That photographs belonging to such renowned painters as Lismer and Johnston did not come to light in public collections until after their deaths suggests that they shared this attitude toward photography.

This article has acknowledged the custodial value placed by Johnston and Lismer and their families on the artists' wartime photographic source material. It has also recognized in its discussion of Varley that safekeeping source material for paintings does not always happen, leaving unanswered questions. It has highlighted some of the issues facing photographers and artists in a time of brutal world upheaval, when public expectations for dramatic war images were heightened. The concepts of authenticity, truth, and realism held fast, but ultimately, meeting the demand for spectacle trumped all, as Beaverbrook's attitude to composite war imagery demonstrates. Photographer and painter alike often resorted to a variety of compositional aids to meet popular and official requirements if not, indeed, their own needs. Composite photography was a practice deplored by many, but at the same time it was embraced by others as a tool to achieve "authenticity." If the relationship between art and photography has always been complicated, during the First World there were the added issues of propaganda, censorship, and official and unofficial expectations. Thanks to the families of Lismer and Johnston and the institutions that now safeguard their archives and source material we are able to explore the complex relationship between art and photography during a time when it had a particularly distinctive character.
Notes

1 Augustus John to Dorothy McNeill, [January 1918], National Library of Wales, Augustus John Papers, GB 0210 MSAUGJOHN, 22778D.

2 A recent book on the subject of nineteenth-century artists and photography is Elizabeth W. Easton, ed., Snapshot: Painters and Photography, Bonnard to Vuillard (New Haven: Yale University Press, 2011).

3 Paul Gough, A Terrible Beauty: British Artists in the First World War (Bristol: Sansom and Company, 2010), 67.

4 See, for example, Mary Warner Marien, Photography, A Cultural History, 3rd ed. (New Jersey: Prentice Hall, 2011).

5 From the late nineteenth century to the early years of the twentieth century, Pictorialism dominated much photographic practice. Influenced by the art of the time, including Impressionism, pictorialist approaches sought to separate photography as art from any scientific purposes. For many practitioners, the collaging of parts from different photographs into a single composite image was a perfectly acceptable practice. For others, it was not.

6 For more on this see, M.T. Jolly, "Fake Photographs: Making Truths in Photography," PhD diss., University of Sydney, 2003.

7 Known as Franz after 1927.

8 This research is found in the Canadian War Museum (CWM) Curatorial Research Files, Canadian Artists' Photographs.

9 At the CWM, these are known as the Canadian Expeditionary Force (CEF) official war photographs, and a contemporary finding aid is part of the collection. The acquisition number of the whole is CWM 19920085, with each individual image having its own subsequent number. It is, however, likely that the total number of official photographs actually taken far exceeds the figure catalogued.

10 The eleven photographs are found in the Lismer archival fonds, CWM 19790051. The original nitrite negatives were donated to the CWM by the artist's daughter, Marjorie Bridges, in 1979.

11 Currently, these photographs are not catalogued but they are found in Library and Archives Canada (LAC), Mary Bishop Rodrik and Franz Johnston fonds, R 320-0-4-E, Franz Johnston Photographs.

12 See Andrew C. Rodger, "Amateur Photography by Soldiers of the Canadian Expeditionary Force," Archivaria 26 (Summer 1988): $163-68$.

13 LAC, Records of the Department of Militia and Defence, Record Group 9, III, Box 202638, Canadian Division Routine Orders, vol. 1, Routine Order No. 189 (20 March 1915).

14 In December 1917, Sir Max Aitken was offered a peerage and took the title 1st Baron Beaverbrook. For clarity, he will be referred to as Lord Beaverbrook throughout this article.

15 LAC, Borden Papers, MB26, H1, vol. 64, p. 32556, microfilm reel C-4311.

16 For more on this subject see Tim Cook, "Documenting War and Forging Reputations: Sir Max Aitken and the Canadian War 
Records Office in the First World War," War in History 10, 3 (2003): 265-95.

17 For recent research on Canadian war photography, see Ann Thomas with Anthony Petiteau, The Great War: The Persuasive Power of Photography (Ottawa: National Gallery of Canada, 2014).

18 The photographs created under the patronage of the War Records Office were vetted before they could be viewed publicly. That both vetted and non-vetted photographs have survived gives some credence to Beaverbrook's conclusion that as well as commissioning propaganda he was making a documentary archive.

19 For more on this, see my article, "Words and Pictures: Writing Atrocity into Canada's First World War Official Photographs," The Journal of Canadian Art History/Annales d'histoire de l'art canadien 31, 2 (2011).

20 See for example Peter Robertson, "Canadian Photojournalism during the First World War," History of Photography 2, 1 (January 1978): 44. Endnote cites Canadian Daily Record, London (8 August 1917): 3.

21 New Exhibition of Canadian War Photographs in Colour, 1919, CWM, Hartland Molson Research Centre, RARE D 522 G7 S6.

22 See Peter Robertson, Relentless Verity: Canadian Military Photographers since 1885 (Toronto: University of Toronto Press, 1973).

23 Robertson, Relentless Verity, 12. During this period, the practice of fake photography was certainly known. Both Castle and RiderRider were likely to have been well aware of the ongoing debates surrounding its use but it is difficult to ascertain how widespread this was. Martin Jolly attributes the criticism of Castle's composites only to Rider-Rider. Photos: W.I. Castle/Canada. Dept. of National Defence/Library and Archives Canada/PA-000648 and PA-130113.

24 See for example, "Going Over the Top: A Charge by the Canadian Troops on the Somme Front," Daily Mirror, London, 16 October 1916.

25 For more on this, see Brandon, "Words and Pictures."

26 The most thorough account of Canadian participation in the First World War is to be found in Tim Cook's two-volume history, At the Sharp End: Canadians Fighting the Great War 19141916 (Toronto: Penguin Canada, 2007) and Shock Troops: Canadians Fighting The Great War 1917-18 (Toronto: Penguin Canada, 2008).

27 Richard Jack, The Second Battle of Ypres, 22 April to 25 May 1915, 1917, oil on canvas, $371.5 \times 589 \mathrm{~cm}$, CWM, Beaverbrook Collection of War Art (BCWA), 19710261-0161.

28 Maria Tippett, "The History of the Canadian War Memorial Scheme as a Study of Patronage and Visual Record of the Great War," PhD diss., University of London, 1982, 98-100. Note that Beaverbrook, living in England, mostly hired British artists because he was more familiar with them.

29 Accounts of Varley's war commission are to be found in Christopher Varley, FH. Varley: A Centennial Exhibition (Edmonton: Ed- monton Art Gallery, 1981) and Maria Tippett, Stormy Weather: F.H. Varley—A Biography (Toronto: McLelland \& Stewart, 1998).

30 Lismer's war artist service is admirably covered in Gemey Kelly, Arthur Lismer: Nova Scotia, 1916-1919 (Halifax: Dalhousie Art Gallery, 1982).

31 The most complete account of Johnston's war artist service is Shana Faust "Picturing the Great War: Frank Johnston's RAF Paintings and the Authority of the Photographic Record," Major Research Paper (Toronto: York University, Toronto, 2000).

32 Peter Mellen, The Group of Seven (Toronto: McClelland and Stewart, 1970), 74.

33 Frederick Varley, The Sunken Road (sketch), c. 1918-19, oil on wood panel, $21.3 \times 27 \mathrm{~cm}$, Art Gallery of Ontario, 71.27, gift of Mrs. Donald McKay, Toronto, 1971; donated by the Ontario Heritage Foundation, 1988.

34 Tippett, Stormy Weather, 117.

35 Maria Tippett, Art at the Service of War: Canada, Art, and the Great War (Toronto: University of Toronto Press, 1984), figs. 13 and 14, and Stormy Weather, between pages 84 and 85.

36 Tippett, Stormy Weather, 117.

37 William Ivor Castle, The Battlefield after a Canadian Charge, October 1916, LAC, PA-000868 (formerly PA-868). At the CWM, this same photograph is catalogued as 19920044-841.

38 A note reading "Not for sale or reproduction" appeared handwritten beneath the CWM's print of this photograph before the album in which it was originally contained was disassembled as a preservation measure in 2005. A photocopy of the original album can be consulted in the CWM's photo archives, where the note can be clearly seen. The original photograph number marked on the print is O-940. For more information on the presence of dead bodies in war art and photography see my article, "Words and Pictures," and my chapter "Above or Below Ground?: Depicting Corpses in First and Second World War official Canadian War Art" in Bearing Witness: Perspectives on War and Peace from the Arts and Humanities, ed. Sherrill Grace, Patrick Imbert, and Tiffany Johnstone (Montreal: McGill-Queen's University Press, 2012): 93-106.

39 Frederick Varley, Shell-torn Trees, 1918, watercolour over graphite on wove paper, $25.4 \times 35.3 \mathrm{~cm}$, National Gallery of Canada, Vincent Massey Bequest, 1968, National Gallery of Canada, 15556.

40 The relevant letters are in LAC, Frederick Horsman Varley fonds, R429-0-9-E (formerly MG30-D401).

41 Tippett, Stormy Weather, 117.

42 Tippett, Stormy Weather, 117.

43 Lawrence Sabbath (1915-93) interview with Frederick Varley, 1960. A typescript of this interview is found in the archives of the Agnes Etherington Art Centre, Kingston. Sabbath was a drama and visual arts critic for the Montreal Star (1957-79), the Montreal Gazette (1979-87), and for other newspapers and magazines including the Toronto Star, the New York Times, Saturday Night, and Vie des arts. 
44 Frederick Varley, quoted in Charles Hill, The Group of Seven: Art for a Nation (Ottawa: National Gallery of Canada, 1995), 65.

45 Major-General Commanding Military District No. 6 to Arthur Lismer, 29 June 1918, CWM, GMAC, Arthur Lismer fonds, 19790051-001.

46 Kelly, Arthur Lismer, 20. In the exhibition catalogue endnote, Kelly cites Lismer's daughter's unpublished manuscript as the source of this information.

47 The photographs, postcards, and textual material are found in the CWM catalogued as 19790051 as a whole. The sixteen postcards and eleven nitrite negatives are catalogued separately by item number in either the Arthur Lismer archival fonds or the photography collection.

48 David R. Gray, "Carrying Canadian Troops: The Story of RMS Olympic as a First World War Troopship," Canadian Military History 11 (Winter 2002): 61. According to Gray, she was first painted in dazzle in April 1917 and was repainted with an entirely different design at least once during the war.

49 See for example Arthur Lismer, Dazzle Ship at Sea, 14 December 1918, pastel on paper, 23.5 x $29.8 \mathrm{~cm}$, CWM, BCWA, 19720256011; Harbour Houses and Dazzle Ship, undated, graphite on paper, 35 x 43 cm, CWM, BCWA, 19720256-035; Woolnough's Restaurant, 1918-19, carbon pencil on paper, $35 \times 43 \mathrm{~cm}$, CWM, BCWA, 19720256-095.

50 Gray's postcard is illustrated on p. 57 in his article. The original is in the Maritime Museum of British Columbia, cat. no. 989.02. Unfortunately, it is not one of the sixteen picture postcards retained in the CWM's Lismer fonds.

51 Of note, in the context of this article, is the fact that although his name is clearly marked on the postcard, MacAskill is not noted in the CWM cataloguing as the photographer.

52 Lismer, R.M.S. Olympic in Halifax Harbour, c. 1918-19, photograph, 12 x $17.5 \mathrm{~cm}$, CWM, GMAC, Arthur Lismer fonds, 19790051-024.

53 See Lismer, Four-Funnelled Ship at Dock, 1918, crayon on paper, 35.5 x $43.5 \mathrm{~cm}$, CWM, BCWA, 19720256-030. Note that even here, the ship is not identified as the Olympic.

54 Frank Johnston to Eric Brown, 22 October 1918 (National Gallery of Canada Archives) NGCA, War Artists, 5.42-J, Johnston, Francis $\mathrm{H}$.

55 Frank Johnston to Eric Brown, 2 August 1918, NGCA, 5.42-J, Canadian War Artists, Johnston, Francis H.

56 Currently, these photographs are not catalogued but they are found in LAC, Mary Bishop Rodrik and Franz Johnston fonds, R 320-0-4-E, Franz Johnston photographs.

57 Faust, "Picturing the Great War," 2.

58 Faust, "Picturing the Great War," 2, n.3.

59 Frank Johnston to Eric Brown, 22 August 1918, NGCA, War Artists, 5.42-J, Johnston, Francis H.
60 Frank Johnston, A Tragic Incident, c. 1918, watercolour and gouache on paper, $72 \times 57.5 \mathrm{~cm}$, CWM, BCWA 19710261-0267.

61 Frank Johnston, "Notes on War Art," LAC, Mary Bishop Rodrik and Franz Johnston fonds, R 320-0-4-E vol. 2, file 2.16, Manuscripts-Notes on war art (World War II ), n.d. I believe the manuscript was likely written during or just after the Second World War since it refers to his 1942 shipbuilding picture commission The Birth of a Navy, 1942, oil on Masonite, 29.25 x 39.25 (sight), collection H.M.C.S. York, Toronto, Ontario.

62 Faust, "Picturing the Great War," 22.

63 Johnston, As It Looks Over the Side, 1918, gouache on art board, $57.9 \times 72.1 \mathrm{~cm}$, CWM, BCWA, 19710261-0251.

64 LAC also acquired the negative.

65 Varley, F.H. Varley, 52. In note 71 a link is made directly to Frederick Varley by way of the 1960 cited interview the artist had with Lawrence Sabbath.

66 Mellen, The Group of Seven, 74.

67 For more on this see my article, “'A Unique and Important Asset?' The Transfer of the War Art Collections from the National Gallery of Canada to the Canadian War Museum," Material History Review 42 (Fall 1995): 67-74.

68 See CWM, War Artist File, Lismer, Arthur. 